DOI https://doi.org/10.30525/978-9934-26-000-1-11

\title{
ПРОМОЦІЯ НОВОЇ МАГІСТЕРСЬКОЇ ПРОГРАМИ ЧЕРЕЗ ТЕХНОЛОГІЮ ВІДЕОСКРАЙБІНГУ: КЕЙС УНІВЕРСИТЕТУ ГРІНЧЕНКА
}

\author{
Нетреба М. М. \\ кандидат наук із соиіальних комунікаиій, \\ доиент кафедри реклами та зв 'язків із громадськістю \\ Соколовська М. О. \\ студентка IV курсу \\ Інститут журналістики Київського університету \\ імені Бориса Грінченка \\ м. Київ, Украӥна
}

У сучасних умовах реальної конкуренції на ринку освітніх послуг важливо не тільки створити якісний сучасний освітній продукт, а й ефективно про нього розповісти потенційній аудиторії. Для успішної промоції нової магістерської програми потрібна не тільки якісна організація рекламної кампанії за допомогою сучасних технологій, а й пошук та впровадження нових інструментів для комунікації/взаємодії 3 цільовою аудиторією. Таким інноваційним інструментом є мальовані ролики в техніці скрайбінгу, які сьогодні мають величезну популярність завдяки оригінальному та незвичайному способу подачі матеріалу. Такі ролики прості, ефектні, схожі на мультфільми і допомагають за кілька хвилин доступно і зрозуміло донести до аудиторії складну інформацію про освітній продукт. А найголовніше - вони сприяють ефективному запам'ятовуванню інформації.

Виходить, що в процесі скрайбінгу ми активно залучаємо обидві півкулі мозку: поки права півкуля відповідає за візуальне та естетичне сприйняття, ліва розвиває наше логічне мислення. У результаті ми починаємо більш чітко і структурно сприймати інформацію, а завдяки знакам і образам - без праці запам'ятовувати ії [2].

Відеоскрайбінг - це динамічний вид скрайбінгу; особливий відеоролик, у якому зображення з'являються ніби з-під пера, ручки, маркера. Такий ролик може бути представлений у вигляді статичних схем / графіків, скрайб-малюнків, скрайб - розповідей (коміксів), простих надписів, виготовлених в особливому стилі [1].

Київський Університет імені Бориса Грінченка активно використовує відеоскрайбінг для промоції освітніх проєктів, презентації нових освітніх програм для абітурієнтів, для інформування освітян та звітності перед ними, для інтерактивного навчання, а також для соціальної роботи вищої школи та розважального освітнього контенту. 
Тому метою є дослідження відеоскрайбінгу як новітнього інструменту рекламної стратегії, здатного ефективно впливати на цільову аудиторію через візуалізацію інформації на прикладі промоції нової магістерської програми Університету Грінченка.

У 2020 році Інститут журналістики Київського університету імені Бориса Грінченка представив нову магістерську програму «Контентпродюсування цифрових медіапроєктів», яка включає сучасні трендові дисципліни [3]. Зокрема програма дасть змогу здобути компетентності для управління складними медіапроєктами, які передбачають багатоплатформність і використання цифрових можливостей контенту: мобільних додатків, мультимедійних книг, відеоігор, онлайн-курсів, вебсеріалів.

Промоція нової магістерської програми «Контент-продюсування цифрових медіапроєктів» включає комплекс заходів, спрямованих на висвітлення інформації про особливості, переваги та сучасність програми шляхом використання цифрових та друкованих матеріалів, рекламу освітнього продукту в digital-форматі та залучення цільової аудиторії через загальноуніверситетські івенти.

Просування даного освітнього продукту включає такі етапи:

- Підготовка інформаційного поля до запуску магістерської програми: пресанонсування, інтерактивні активації 3 цільовою аудиторією тощо.

- Інформування про існування магістерської програми якомога більшої кількості людей і вибудовування комунікації щодо пропозиції освітніх послуг між Університетом і цільовою аудиторією. абітурієнта.

- Спонукання до дії (подати заявку на вступ) потенційного

Креативною складовою рекламної кампанії став промо-ролик, виконаний у техніці відеоскрайбінгу, що демонструє основні компетенції, набуті студентами магістерської програми «Контент-продюсування цифрових медіапроєктів». Промо-ролик тривалістю в 1 хвилину 44 секунди був змонтований у програмі VideoScribe [4]. Ця англомовна програма має велику біобліотеку малюнків, музичну галерею, а також функцію запису голосу. Готові проєкти користувач може експортувати відразу в соціальні мережі або на YouTube [5].

Сюжет промо-ролику обертається навколо такої проблеми: абітурієнт прагне створити свій проєкт та успішно його реалізувати, але не знає як, й ії рішення - здобуття освіти за новою магістерською програмою, що надасть відповідні знання та навчить відповідних компетенцій.

Структура промо-ролику новітньої магістерської програми складається з трьох частин: вступу, основної частини та Call To Action. Вступ описує інсайтову ситуацію, в якій перебуває цільова аудиторія програми «Контент-продюсування цифрових медіапроєктів», а саме абітурієнтів, які цікавляться технологічними інноваціями та прагнуть реалізувати свою бізнес-ідею. Далі надається інформація щодо вище наведеної магістерської програми: основні трендові дисципліни, які професії 
абітурієнт опанує після закінчення навчання та які переваги програма має у порівнянні з іншими. Ця частина має на меті допомогти майбутньому студентові зрозуміти, чи підходить йому ця програма, та проінформувати про іiі переваги і унікальність. Нарешті останньою ланкою промо-ролику стає заклик до вступу у визначений 3ВО, де абітурієнт навчиться професіонально і комплексно продюсувати медіапроєкти за допомогою інноваційних інструментів.

Візуальне наповнення ролику включає в себе графічні зображення - схеми, малюнки, що виконані в одній кольоровій та стильовій гамах, а також використання двох корпоративних шрифтів й айдентики Університету Грінченка.

Промо-ролик був розміщений в соціальних мережах Facebook, Instagram, на сайті Інституту журналістики та на офіційному каналі YouTube, а також на інших освітніх онлайн-платформах та ресурсах. Одним із перших про нову магістерську програму проінформував офіційний портал Київської міської державної адміністрації [6]. Також промо-ролик активно використовувався під час івенту для абітурієнтів «День відкритих дверей ОНЛАЙН».

Скористаємося даними вебаналітики, що дозволяє отримати статистичні дані з різних платформ щодо охоплення відеоскрайбу за весь період від моменту публікації рекламного ролику до початку вступної кампанії 2020 року. Загалом сумарна кількість переглядів даного відеоскрайбу склала близько 10 тисяч переглядів. Зокрема найбільше охоплення отримала публікація в соціальній мережі Instagram - 4981 перегляд.

Результатом рекламної кампанії щодо просування нової магістерської програми «Контент-продюсування цифрових медіапроєктів» стали дані вступної кампанії 2020 року: на ліцензований обсяг у кількості 20 місць, серед них 6 бюджетних, було подано 79 заяв. Після проведення фахових випробувань на нову магістерську програму було зараховано 14 магістрантів [7].

Згідно з результатами вступної кампанії 2020 року кейс Університету Грінченка щодо промоції нової магістерської програми через технологію відеоскрайбінгу доводить свою ефективність.

Даний промо-ролик став ефективним та успішним інструментом донесення до цільової аудиторії повної, відкритої та актуальної інформації про ЗВО та її освітньо-професійні програми, а також для підтримки позитивного образу Університету, формування громадської думки про популярні професії серед абітурієнтів.

Таким чином, реалізація промоції нових освітніх програм із використанням технології відеоскрайбінгу стає важливою складовою рекламної стратегії для закладів вищої освіти. 


\section{Література:}

1. Сорока Т.В. Скрайбінг як сучасна форма візуалізації навчального матеріалу [Електронний ресурс]. Географія. - Харків:ТОВ Видавнича група «Основа». - No 16 (284). - 2015. - Режим доступу: http://journal.osnova.com.ua/article/51806.

2. Петровский П.В. Скрайбинг. Объяснить просто: учебное пособие / Петровский П.В., Любецкий Н. С., Кутузова М.А. Эксмо-Пресс. 2016. -208 c.

3. ОСВІТНЬО-ПРОФЕСІЙНА ПРОГРАМА. 061.00.06 КонтенТпродюсування цифрових медіапроєктів другого (магістерського) рівня вищої освіти Київського університету імені Бориса Грінченка, Київ, 2020. Режим доступу:https://kubg.edu.ua/images/stories/Departaments/ nmc.kmn/osv_pr/OPP_061_SRMR.pdf.

4. Промо-ролик, розроблений у техніці відеоскрайбінгу для промоції магістерської програми «Контент продюсування цифрових медіапроєктів». - 2020. - Київ. Режим доступу: https://youtu.be/MON7Jm4pks8.

5. Videoscribe [Електронний ресурс]. Режим доступу: https://www.videoscribe.co/en.

6. Від креатора до тренд-аналітика: у столичному університеті імені Бориса Грінченка представили нову магістерську програму 3 продюсування цифрових медіапроєктів: стаття [Електронний ресурс]. Режим доступу: https://kyivcity.gov.ua/news/vid_kreatora_do_trendanalitika_u_stolichnomu_universiteti_imeni_borisa_grinchenka_predstavili novu_magistersku_programu_z_prodyusuvannya_tsifrovikh_mediaproyekti

7. Результати вступної кампанії 2020 року на магістерську програму «Контент продюсування цифрових медіапроєктів» [Електронний pecypc]. Режим доступу: https://vstup.osvita.ua/y2020/r27/56/731344/. 